\title{
Nonlinear ODE mathematical analysis of the insulin- glucose model in the presence of a condition in glycemia function $\mathrm{H}(\mathrm{G})$.
}

\section{Research Article}

Keywords:

Posted Date: July 20th, 2021

DOI: https://doi.org/10.21203/rs.3.rs-323028/v2

License: (c) (i) This work is licensed under a Creative Commons Attribution 4.0 International License. Read Full License 


\section{Abstract}

The authors have requested that this preprint be withdrawn due to author disagreement.

\section{Full Text}

The authors have withdrawn this preprint from Research Square. 